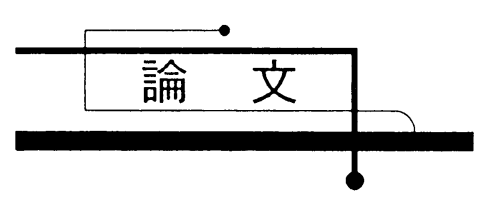

\title{
鉛直管での気液対向流制限に対する流体物性値の影響*
}

\section{Effects of Fluid Properties on Countercurrent Flow Limitation in Vertical Pipes}

\author{
村 瀬 道 雄** \\ MURASE Michio
}

\author{
楠 木 貴世志** \\ KUSUNOKI Takayoshi
}

\author{
山 本 泰 功*** \\ YAMAMOTO Yasunori
}

$\begin{array}{cllll}\text { 合 田 頼 } \text { 人 }^{\dagger} & \text { 林 公 } \text { 祐 }^{\dagger} \text { 細 川 茂 } \text { 雄 }^{\dagger} & \text { 冨 山 明 男 } \\ \text { GODA Raito } & \text { HAYASHI Kosuke } & \text { HOSOKAWA Shigeo } & \text { TOMIYAMA Akio }\end{array}$

\begin{abstract}
To evaluate effects of the diameter on countercurrent flow limitation (CCFL) in vertical pipes, in our previous study, we classified CCFL into CCFL-L at the sharp-edged lower end, CCFL-U at the sharp-edged upper end, and CCFL-P inside the vertical pipe with round-edged upper and lower ends, and we found that the characteristic length in the Wallis parameter, $w=D^{(1-\beta)} L^{\beta}$ (where $D$ and $L$ respectively denote the diameter and the Laplace capillary length), is respectively $\beta=0,1$ and $\beta \approx 0.5$ for CCFL-L, CCFL-U and CCFL-P. In this study, we evaluated effects of fluid properties on CCFL in vertical pipes by using existing CCFL data. The most effective fluid properties is the liquid viscosity and we selected the viscosity ratio of gas and liquid $\left(\mu_{G} / \mu_{L}\right)$ as a dimensionless parameter. From effects of $\mu_{G} / \mu_{L}$ on the slope $m$ and constant $C$ in the Wallis correlation, we classified three regions of large positive interrelations of $m$ and $C$ with $\mu_{G} / \mu_{L}$ for small $\mu_{L}$ (room-temperature to high-temperature water), small interrelations of $m$ and $C$ with $\mu_{G} / \mu_{L}$ for medium $\mu_{L}$ (low-concentration glycerol water solution), and the large negative interrelation of $m$ with $\mu_{G} / \mu_{L}$ for large $\mu_{L}$ (high-concentration glycerol water solution). We obtained exponent functions of $\mu_{G} / \mu_{L}$ for $m$ and $C$ in the case of the small $\mu_{L}$ (room-temperature to high-temperature water) for CCFL-L and CCFL-U except CCFL-P without high-temperature CCFL data.
\end{abstract}

Keywords: Countercurrent flow limitation, Vertical pipe, Fluid properties

\section{1. 緒 言}

加圧水型原子炬 (PWR: Pressurized Water Reactor) の一次系では、通常運転時には液単相で あるが、想定される事故条件では減圧沸騰や炉心 での崩壊熱により蒸気が発生して気液二相にな り、一次系の各所で気液対向流が生じる。一次系 圧力が二次系圧力である約 $7 \mathrm{MPa}$ 以下になると、 流路が狭い部分で対向流制限 (CCFL: Countercurrent Flow Limitation）を生じる場合がある。本 研究では、一次系の一部である蒸気発生器の伝熱 管と加圧器サージ管での CCFL を対象としてお
り、前者は逆U字管であり、後者は鉛直管、鉛直 90 度エルボ、複数のエルボを含む微傾斜管で構 成されている。CCFL は、フラッディング開始後 の準定常状態での時間平均の気液体積流束 $\left(J_{G}\right.$ と $J_{L}$ ）の関係で定義している。

鉛直管での気液対向流に関しては多くの従来 研究[1,2]があるが、管内でのフラッディング開始 に関する研究が多く、CCFL 特性に関する研究は 少ない。本研究の対象である蒸気発生器の伝熱管 は下端がシャープエッジであり、加圧器サージ管 の鉛直管は上端がシャープエッジである。そこで、

* 2017.2.22 受付

** 株式会社 原子力安全システム研究所 テ919-1205 福井県三方郡美浜町佐田 64 号

TEL: (0770)37-9100 FAX: (0770)37-2009 E-mail: murase@inss.co.jp

*** 株式会社 原子力安全システム研究所 (現 : 北海道大学) †神戸大学大学院工学研究科 
シャープエッジ下端での CCFL (CCFL-L) を対象 として空気・水実験を行い、Wallis 相関式におい て代表長さ $w$ として直径 $D$ を用いると CCFL 特 性をよく整理できることを明らかにした[3]。また、 蒸気・水実験 [4] と凝縮実験 [5]を行い、CCFL-L の 相関式を導出した[5]。シャープエッジ上端での CCFL（CCFL-U）については、空気・水実験を行 い $w$ としてラプラス長さ $L$ を用いるべきである ことを明らかにし[6]、従来データ [7]を含めて CCFL-U の相関式を導出した[8]。また、前報[9] では、上端・下端ともラウンドエッジでの従来デ ータを用いて管内での CCFL (CCFL-P) について 検討し、 $w \approx D^{0.5} L^{0.5}$ で整理できることを明らかに して CCFL-P の相関式を導出した。これらにより 鉛直管の直径が CCFL に及ぼす影響が明らかに なったが、高温高圧の蒸気・水系での CCFL デー タが少なく流体物性值の影響は明らかにされて いない。最近、Ilyukhin ら[10]による $D=20 \mathrm{~mm}$ 、 圧力 $P=0.6 \sim 4.1 \mathrm{MPa}$ での CCFL 測定に関する文 献を入手した。

本報では、著者らによる CCFL データ $[3,4,6]$ と従来データ $[1,2,7,10,11]$ を用いて流体物性值 が鉛直管での CCFL に及ぼす影響について検討 した。本研究では、PWR の一次系で CCFL が生 じやすくなる $7 \mathrm{MPa}$ 以下の蒸気・水系への適用を 目標にしており、特に蒝気発生器の伝熱管の下端 での CCFL-L と加圧器サージ管の上端での CCFL-Uを重視している。

\section{2. 従来研究の概要}

\subsection{CCFL の一般式}

原子力プラントの過渡・事故解析では、例えば 一次元二流体モデルに基づいてフラッディング 状態での落下水量を計算できるが、計算精度がよ くないため、落下水量の計算には Wallis [1]による CCFL 相関式が広く使用されている。

$$
\begin{aligned}
& H_{G}^{* 1 / 2}+m H_{L}^{* 1 / 2}=C \\
& H_{k}^{*}=J_{k}\left\{\frac{\rho_{k}}{g w\left(\rho_{L}-\rho_{G}\right)}\right\}^{1 / 2},(k=G \text { or } L)
\end{aligned}
$$

ここで、 $g\left[\mathrm{~m} / \mathrm{s}^{2}\right]$ は重力加速度、 $J[\mathrm{~m} / \mathrm{s}]$ は体積流束、 $H^{*}$ [-] は無次元体積流束、 $w[\mathrm{~m}]$ は代表長さ、 $\rho$ $\left[\mathrm{kg} / \mathrm{m}^{3}\right]$ は密度であり、式(1)の勾配 $m$ と定数 $C$ は
実験により決定される。Bankoff ら[12]は、式(2) の代表長さ $w$ を次式で表わしている。

$$
\begin{aligned}
& w=D^{(1-\beta)} L^{\beta}, \quad 0 \leq \beta \leq 1 \\
& L=\left[\sigma /\left\{g\left(\rho_{L}-\rho_{G}\right)\right\}\right]^{1 / 2}
\end{aligned}
$$

ここで、 $D[\mathrm{~m}]$ は直径、 $L[\mathrm{~m}]$ はラプラス長さ、 $\sigma$ $[\mathrm{N} / \mathrm{m}]$ は表面張力である。式(2)の $H_{k}{ }^{*}$ は、 $\beta=0$ で Wallis パラメータ $J_{k}^{*}$ に、 $\beta=1$ で Kutateladze パ ラメータ $K_{k}{ }^{*}$ になり、 $J_{k}{ }^{*}$ と $K_{k}{ }^{*}$ は無次元直径 $D^{*}$ を用いて次式により相互に変換できる。

$$
J_{k}^{*}=K_{k}^{*} / D^{* 1 / 2}, D^{*}=D / L,(k=G \text { or } L)
$$

\section{2 制限位置ごとの CCFL 相関式}

著者らは、蒸気発生器の伝熱管のシャープエッ ジ下端における CCFL を対象として、鉛直管での 空気・水実験[3] と蒸気・水実験[4]および逆 U 字 管での凝縮実験[5]を行い、CCFL-L の相関式を導 出した[5]。

$$
\begin{aligned}
& J_{G}^{* 1 / 2}+0.88 J_{L}^{* 1 / 2}=0.76 \pm 0.05, \\
& 5.6<D^{*}<19
\end{aligned}
$$

著者らは、加圧器サージ管の鉛直管のシャープ エッジ上端における CCFL を対象として、 $D=30$, 45, $60 \mathrm{~mm}$ の鉛直管を用いた空気・水実験[6]を行 い、 $D=19 \sim 140 \mathrm{~mm}$ での空気・水実験データ [7] を含めて CCFL-U の相関式を導出した $[8]$ 。

$$
\begin{aligned}
& K_{G}^{* 1 / 2}+0.90 K_{L}^{* 1 / 2}=1.5 \pm 0.1, \\
& 7<D^{*}<51
\end{aligned}
$$

著者らは、式(6)と式(7)を参照し、従来データ を用いて CCFL-P の相関式を導出した[9]。

$$
\begin{aligned}
& K_{G}^{* 1 / 2}+0.90 K_{L}^{* 1 / 2}=\min \left[(1.2 \pm 0.07) D^{*_{1 / 8}}, 1.79\right] \\
& 6.6<D^{*}<38
\end{aligned}
$$

式(6)の導出データには大気圧での蒸気・水実験 [4]を含むが、式(7) と式(8)は空気・水データのみ から導出されており、いずれも高温高圧の蒸気・ 水系への適用性は明らかでない。

併記した $D^{*}$ は相関式の導出に用いた実験条件 
の範囲を示す。定数項の不確かさは実験ごとの相 違の影響が大きい。シャープエッジでも条件によ り CCFL-P が生じる場合があり $[6,9]$ 、式(8)とは 勾配と定数が異なる[9]など、式(6)-(8)に包含され ない CCFL データがある。

\section{3 流体物性值の影響}

鈶直管でのフラッディング開始に対する流体 物性值の影響に関する研究は多いが、CCFLに対 する流体物性值の影響に関する研究は少ない。

Wallis [11]は、上端と下端がラウンドエッジの 鉛直管 $(D=19 \mathrm{~mm})$ で空気とグリセリン水溶液 を用いた実験を行い、Fig. 1 に示す CCFL データ を取得している。また、一部のデータに対して液 相の逆粘性数 $N_{L}$ （浮力と粘性力の比）を用いた 次式を示している。

$$
\begin{aligned}
& J_{G}^{*_{1} / 2}+5.6\left(J_{L}^{*} / N_{L}\right)^{1 / 2}=0.725 \\
& N_{L}=\left[\rho_{L}\left(\rho_{L}-\rho_{G}\right) g D^{3}\right]^{1 / 2} / \mu_{L}
\end{aligned}
$$

液相粘性 $\mu L[\mathrm{~Pa} \cdot \mathrm{s}]$ の最大値は常温水の 3000 倍で あり、Fig. 1 より液相粘性が CCFL 特性の勾配と 定数に大きな影響を及ぼすことは明らかである。 定義式(10)より $N_{L} \propto D^{* 1.5}$ であり、異なる $D$ に対 して $N_{L}$ を用いて整理するのは適切でない[4]。

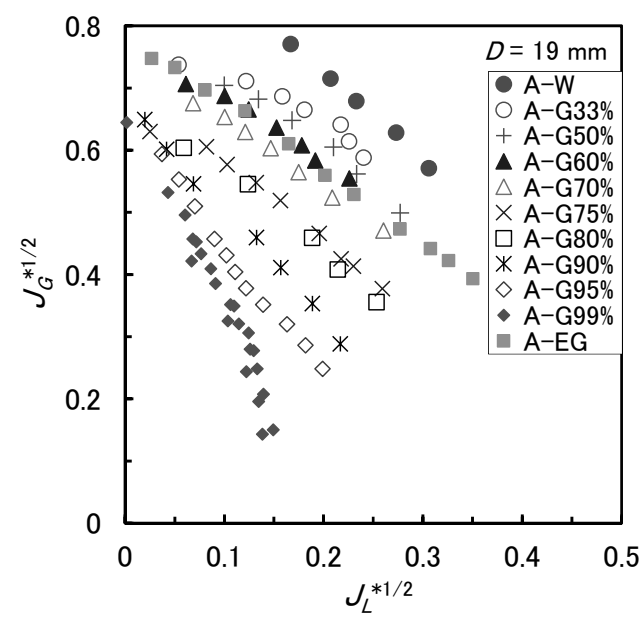

Fig. 1 Effects of liquid viscosity on CCFL [11], A: air, EG: ethylene glycol, G: glycerol, W: water.

Ilyukhin ら[10, 13]は、上端と下端がシャープエ
ッジの鉛直管 $(D=20 \mathrm{~mm})$ で高温高圧の蒸気と 水 $(P=0.6 \sim 4.1 \mathrm{MPa})$ を用いた実験を行い、Fig. 2 に示寸 CCFL データを取得し[10]、式(11)を示し ている[13]。

$$
\begin{aligned}
& K_{G}^{* 1 / 2}+1.25 K_{L}^{* 1 / 2}=1.5 D^{* 1 / 8}\left(\rho_{G} / \rho_{L}\right)^{0.05}, \\
& H / D \geq 20
\end{aligned}
$$

$H[\mathrm{~m}]$ は鉛直管の高さである。式(11)は式(8)と同様 に式(3)で $\beta=0.5$ であるが、直径が大きくなると $\beta=0.5$ を適用できない[9]。Fig. 2 に示すように、 高 $K_{G}{ }^{* 1 / 2}$ では CCFL-L、中 $K_{G}{ }^{*}{ }^{1 / 2}$ では CCFL-U が 生じている (著者らが鉛直管内差圧[10]から判別)。 圧力により境界值が若干異なりグラフ[10]で判別 困難な測定点は表示していないため、CCFL-L と CCFL-U の間に測定点表示がなくなっている。蒸 気・水系に対しては気液密度比 $\rho_{G} / \rho_{L}$ を用いて形 式的にデータ整理できるが、測定例が多い空気・ 水系を含めると $\rho_{G} / \rho_{L}$ ではデータ整理できない $\left(\rho_{G} / \rho_{L}\right.$ は Fig. 1 データにも適用できない)。

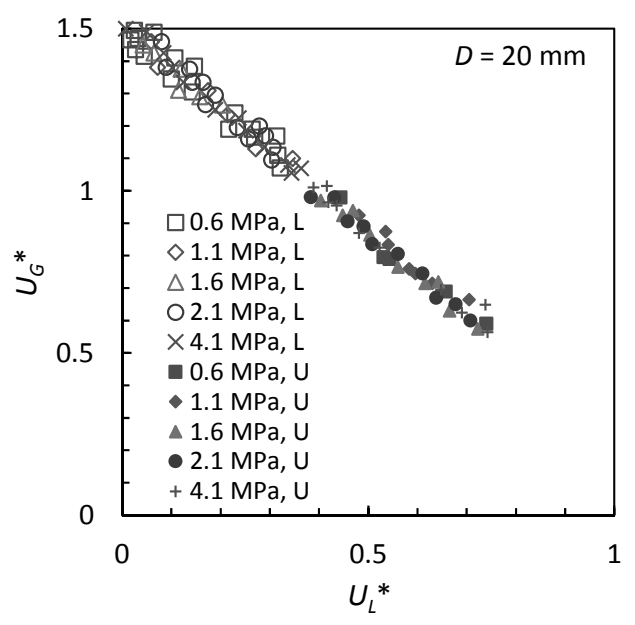

Fig. 2 Effects of pressure on CCFL [10], $U_{k}{ }^{*}=K_{k}^{* 1 / 2} /\left[D^{* 1 / 8}\left(\rho_{G} / \rho_{L}\right)^{0.05}\right]$,

L: CCFL-L, U: CCFL-U.

Zapke and Kröger [14]は、下端がシャープエッジ の鉛直管 $(D=30 \mathrm{~mm})$ で空気とメタノール水溶 液を用いた実験を行い、液相オーネソルゲ数 $O h_{L}$ を用いた次式を提案している。

$$
J_{G}^{* 1 / 2}+J_{L}^{* 1 / 2}=0.52 / O h_{L}^{0.05}
$$




$$
O h_{L}=\mu_{L} /\left(\sigma \rho_{L} D\right)^{1 / 2}
$$

$O h_{L}$ は蒸気・水系では約 $2.5 \mathrm{MPa}$ で極小值を持ち 高温高圧の蒸気・水系には適用できない[4]。

著者らは、下端がシャープエッジの鉛直管を用 いて、 $D=20 \mathrm{~mm}$ での空気・水実験[3] と空気・グ リセリン水溶液実験[4]および $D=14 、 20 、 27 \mathrm{~mm}$ での蒸気・水実験[4]を行ない、Fig. 3 に示す CCFL データを取得し、気液粘性比 $\mu_{G} / \mu_{L}$ を用いた式(14) を導出した[4]。 $J_{L}{ }^{*}{ }^{1 / 2}$ の二次式を用いると極小值 を有することから三次式にしている。

$$
\begin{aligned}
& \frac{J_{G}^{* 1 / 2}}{\left(\mu_{G} / \mu_{L}\right)^{0.07}}=(1.04 \pm 0.05)-3.6\left[\left(\frac{\mu_{G}}{\mu_{L}}\right)^{0.1} J_{L}^{* 1 / 2}\right] \\
& +11\left[\left(\frac{\mu_{G}}{\mu_{L}}\right)^{0.1} J_{L}^{* 1 / 2}\right]^{2}-16\left[\left(\frac{\mu_{G}}{\mu_{L}}\right)^{0.1} J_{L}^{* 1 / 2}\right]^{3}
\end{aligned}
$$

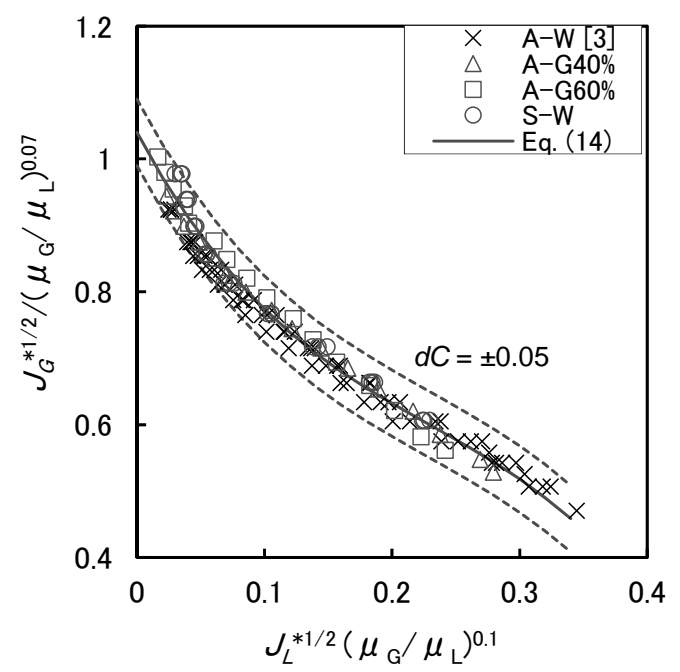

Fig. 3 Effects of fluid properties on CCFL-L [4], A: air, G: glycerol, S: steam, W: water.

Fig. 1 の実験では液相粘性を大きく変更してい るが表面張力が変化し液相密度も若干変化して おり、Fig. 2 の実験では気相密度、液相粘性およ び表面張力の変化が大きい。したがって、特定の 実験条件に対しては流体物性值に関する各種の 無次元量を用いて測定值を整理できるが、著者ら は液相粘性が CCFL 特性に最も影響すると判断 [4]している。液相粘性の無次元量に逆粘性数を用
いると直径に関して悪影響を及ぼすため、ここで は変化量が小さい気相粘性との比 $\mu_{G} / \mu_{L}$ を用いて 流体物性值の影響を評価する。

\section{CCFL 特性の分類}

ここでは、Wallis による CCFL 相関式(1)におけ る勾配 $m$ と定数 $C$ の特徽から CCFL 特性を領域 分けする。

\section{1 気液粘性比の影響}

直径の影響は制限位置により CCFL-L と CCFL-U および CCFL-P で異なるため、 $D=18$ $20 \mathrm{~mm}$ の範囲に限定して気液粘性比 $\mu_{G} / \mu_{L}$ が式(1) の勾配 $m$ と定数 $C$ に及ぼす影響について検討し た。 $\mu_{G} / \mu_{L}$ と $C$ および $m$ との関係を Fig. 4 に示す。
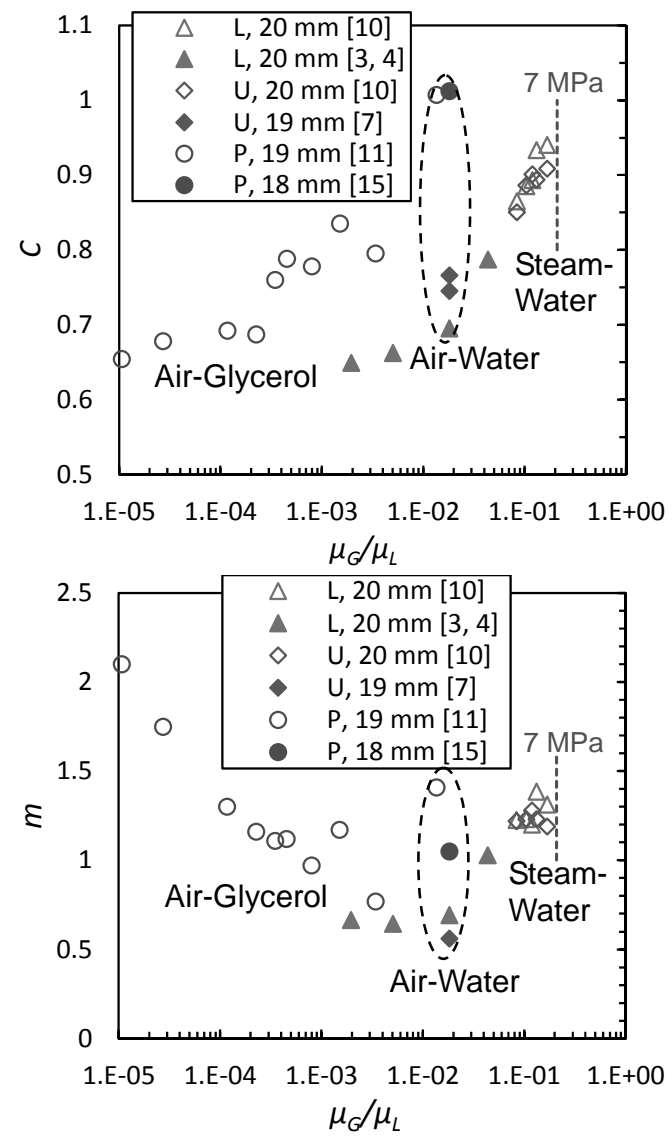

Fig. 4 Effects of $\mu_{G} / \mu_{L}$ on $m$ and $C$, L: CCFL-L, U: CCFL-U, P: CCFL-P.

常温常圧の空気・水を境界にして $\mu_{G} / \mu_{L}$ の影響 が大きい領域と小さい領域に区分できる。空気・ 
グリセリン水溶液では、 $\mu_{G} / \mu_{L}$ の $C$ への影響が中 程度の低濃度領域と $m$ への影響が大きい高濃度 領域に区分できる。つまり、水、低濃度グリセリ ン水溶液、高濃度グリセリン水溶液の 3 領域に区 分できる。この結果より、特定領域での CCFL デ ータを用いて異なる領域に外挿評価できないこ とが明らかである。

CCFL-P では蒸気・水データがなく水領域（常 温水〜高温水）で $\mu_{G} / \mu_{L}$ の影響が一層大きくなる か否か不明である。また、CCFL-P の空気・水デ ータでは Wallis [11]と Suzuki and Ueda [15]とで $m$ の相違が大きく、実験ごとの相違が大きいことに 留意する必要がある。

\section{2 勾配と定数との関係}

CCFL-L と CCFL-U に対する勾配と定数の関係 をFig. 5 に示す。Wallis パラメータでの整理を $C_{W}$ で、Kutateladze パラメータでの整理を $C_{K}$ で示す。 CCFL-Lに関しては、蒸気・水と空気・水とで $m$ と $C$ に明確な相関がある。CCFL-L は $D=20 \mathrm{~mm}$
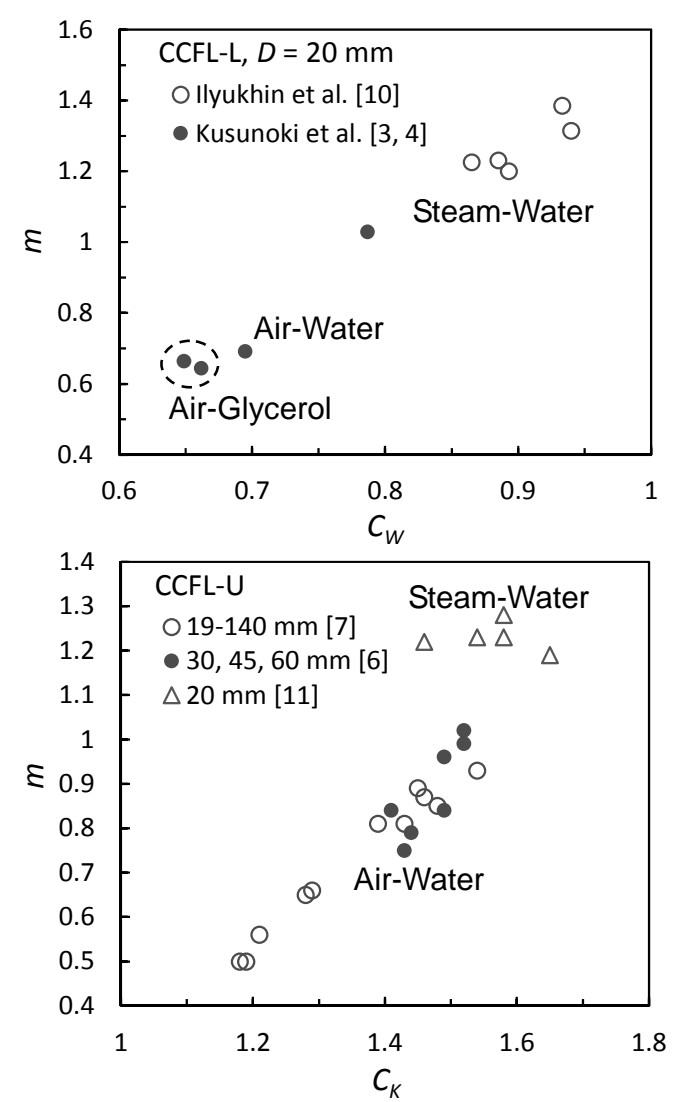

Fig. 5 Interrelation between $m$ and $C$.
のみであるが、CCFL-Uについては $D=19 \sim 140$ mm のデータを含んでおり、Ilyukhin ら[11]の蒸 気・水条件を除いて空気・水条件である。Richter [7]と Doi ら[6]による空気・水データでは、 Kutateladze パラメータで整理しているにもかか わらず $m$ と $C$ が一定值にならず、かつ $m$ と $C$ に 明確な相関がある。この原因は明らかでないが、 $m$ と $C$ に対寸る補正項として $D^{*}$ の影響を関数化 するような明確な相関はない。Fig. 5 は、流体物 性值で定数 $C$ を補正する場合には、勾配 $m$ も補 正する必要があることを示している。

\section{4. 高温高圧の蒸気 · 水系への外挿評価}

\section{1 シャープエッジ下端 CCFL}

CCFL-L に対する $\mu_{G} / \mu_{L}$ の $m$ と $C_{W}$ への影響を Fig. 6 に示す。空気・水条件を境界にして、最小 二乗法を用いて $m$ と $C_{W}$ に対する $\mu_{G} / \mu_{L}$ の指数関 数を求めた。図中の $m 1$ と $C 1$ は水の領域、 $m 2$ と $C 2$ は低濃度グリセリン水溶液の領域である。

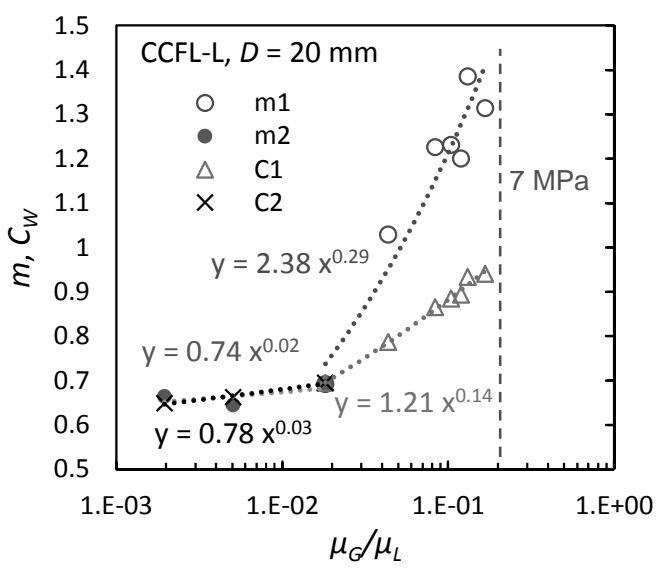

Fig. 6 Effects of $\mu_{G} / \mu_{L}$ on $m$ and $C_{W}$ for CCFL-L.

Fig. 6 における $m$ と $C_{W}$ に対する $\mu_{G} / \mu_{L}$ の指数を 用いて整理した CCFL-L データおよび式(14)に おける $m$ と $C_{W}$ に対する $\mu_{G} / \mu_{L}$ の指数を用いて整 理した CCFL-L データを Fig. 7 に示す。式(14)に おける $\mu_{G} / \mu_{L}$ の指数を用いると、Kusunoki ら $[3,4]$ の測定值 (測定誤差は $J_{G}{ }^{* 1 / 2}$ 換算で \pm 0.01 未満 $)$ と 蒸気発生器伝熱管の実機条件での ROSA-IV/ LSTF データ $\left(J_{L}{ }^{* 1 / 2}\right.$ が小さい方から $P=1 、 3 、 7$ $\mathrm{MPa}$ ）[16]とは比較的よく一致するが Ilyukihin ら [10]の測定值との一致が悪い。一方、Fig. 6 にお 
ける $\mu_{G} / \mu_{L}$ の指数を用いると、Kusunoki ら[3, 4]の 測定值と Ilyukihin ら[10]の測定值とはよく一致す るが ROSA-IV/LSTF データ [16]との一致が悪い。

Fig. 7 に示寸測定值を用いて最小二乗法で CCFL 相関式を求めると、次式になる。

$$
\begin{aligned}
& J_{G}^{* 1 / 2}+2.26\left(\mu_{G} / \mu_{L}\right)^{0.29} J_{L}^{*_{1} / 2} \\
& =(1.2 \pm 0.05) \cdot\left(\mu_{G} / \mu_{L}\right)^{0.14}
\end{aligned}
$$

式(15)を用いて圧力 $7 \mathrm{MPa}$ での CCFL-L を計算 した結果を Fig. 8 に示す。計算值では $0.1 \mathrm{MPa}$ と $4.1 \mathrm{MPa}$ との相違は大きいが、4.1 $\mathrm{MPa}$ と $7 \mathrm{MPa}$ との相違は小さい。この結果は、低圧と中圧での
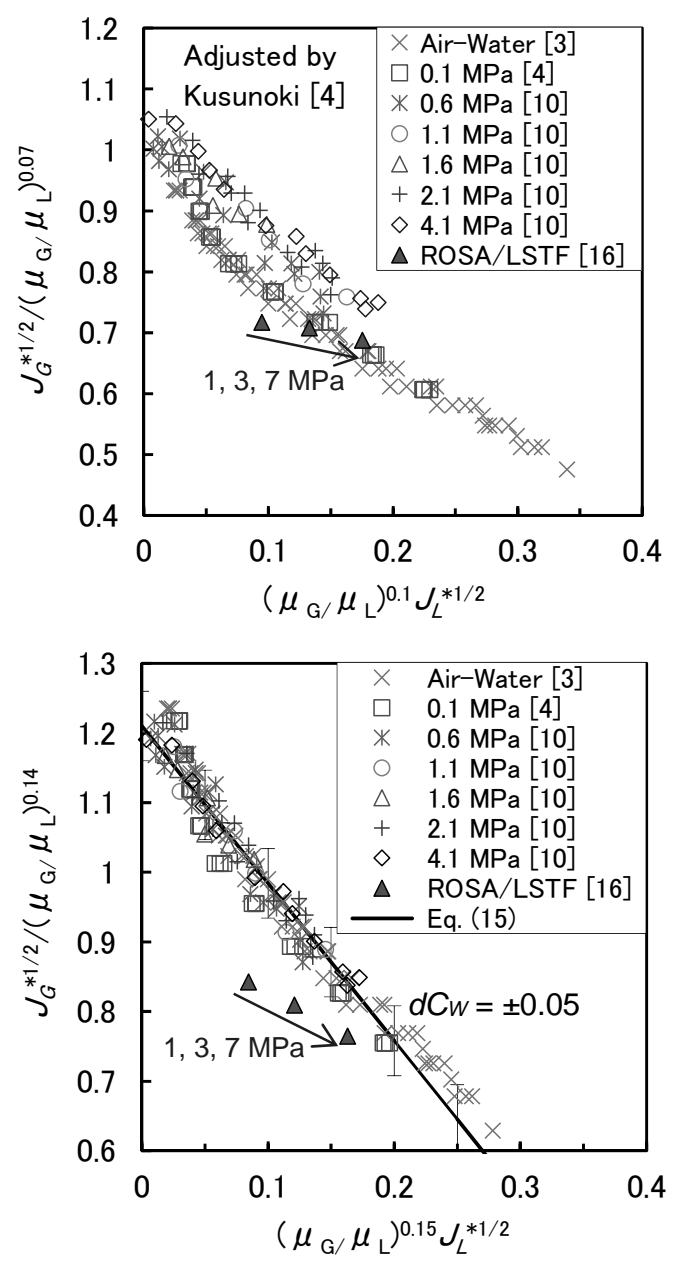

Fig. 7 CCFL-L adjusted by exponent function of $\mu_{G} / \mu_{L}$.

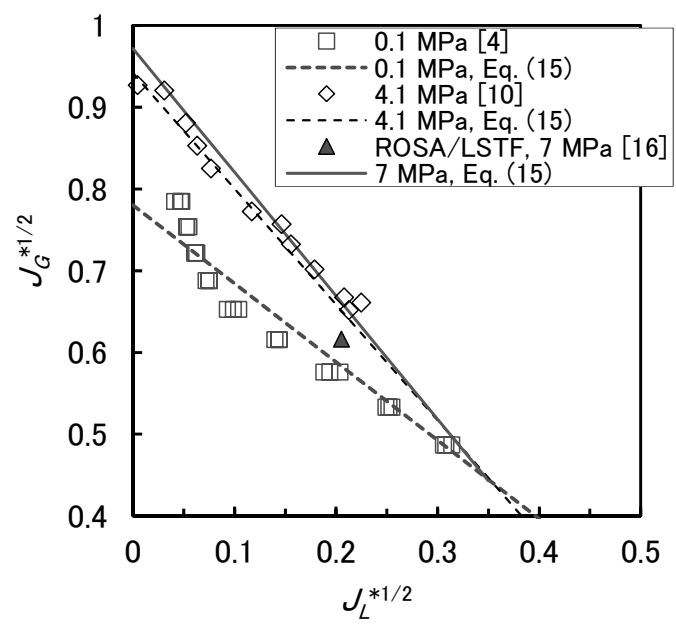

Fig. 8 Effects of pressure on CCFL-L.

測定值から高圧条件を外挿すれば比較的精度よ く推定できることを示唆している。Fig. 7 から推 察されるように、7 MPa での測定値[16]と計算值 との相違は比較的大きい。

蒸気発生器の伝熱管での CCFL-L を評価する場 合には ROSA-IV/LSTF データ [16]を重視して式 (14)を使用することを推奨する（Wallis 型の線形 式は文献[5]を参照)。一般的な鉛直管での CCFL-L を評価する場合には、より多くの測定値に基づく 式(15)を使用することを推奨する。

\section{2 シャープエッジ上端 CCFL}

CCFL-U に対する $\mu_{G} / \mu_{L}$ の $m$ と $C_{K}$ への影響を Fig. 9 に示す。 $\mu_{G} / \mu_{L}$ が一定值である空気・水実験 でも図中に最大值と最小值の範囲を示すように $m$ と $C_{K}$ が大きく変化している (Fig. 5 参照)。

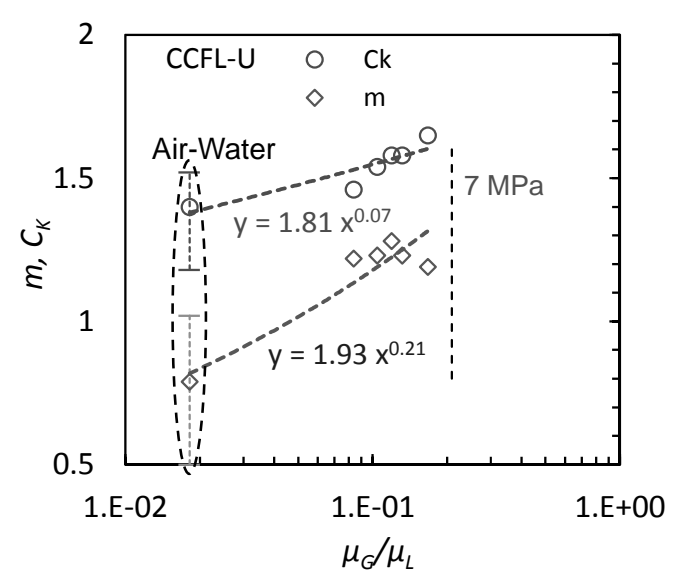

Fig. 9 Effects of $\mu_{G} / \mu_{L}$ on $m$ and $C_{K}$ for CCFL-U. 
このため、Fig. 9 では空気・水条件に対する $m$ と $C_{K}$ の平均值を用いて $\mu_{G} / \mu_{L}$ の指数関数を求めた。 CCFL-U での指数は Fig. 6 に示した CCFL-L での 指数より小さくなっている。

Fig. 9 における $m$ と $C_{K}$ に対する $\mu_{G} / \mu_{L}$ の指数を 用いて整理した CCFL-UデータをFig. 10 に示す。 空気・水では $m$ および $C_{K}$ の実験ごとの相違が大 きいが (Fig. 5 参照)、Fig. 10 では実験ごとの測

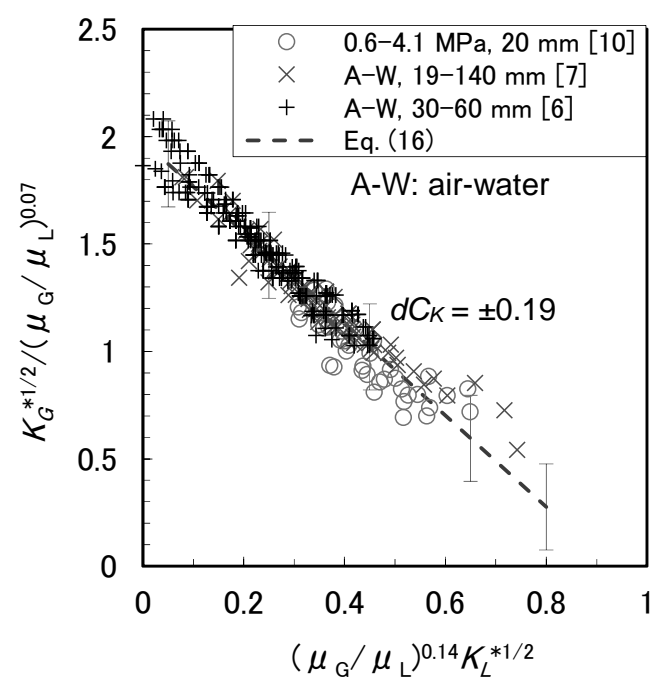

Fig. 10 CCFL-U adjusted by exponent function of $\mu_{G} / \mu_{L}$.

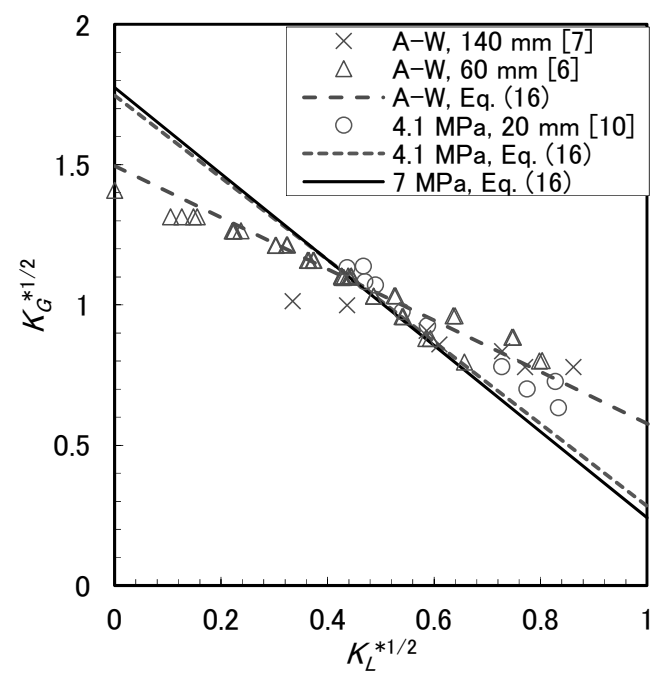

Fig. 11 Effects of pressure on CCFL-U.
定点が中 $K_{G}{ }^{*} 1 / 2$ で相互に交差するため大きなバラ ツキにはなっていない。

Fig. 10 に示す測定值を用いて最小二乗法で CCFL 相関式を求めると、次式になる。

$$
\begin{aligned}
& K_{G}^{*_{1} / 2}+2.13\left(\mu_{G} / \mu_{L}\right)^{0.21} K_{L}^{*_{1} / 2} \\
& =(1.98 \pm 0.19) \cdot\left(\mu_{G} / \mu_{L}\right)^{0.07}
\end{aligned}
$$

式(16)では定数 $C_{K}$ の不確かさ $\pm 0.19(10 \%)$ が式 (15)での不確かさ \pm 0.05 （約 4\%）より大きい。式 (16)では $D=19 \sim 140 \mathrm{~mm}$ での広範囲のデータ群 を対象にしていることによる。

式(16)を用いて圧力 $7 \mathrm{MPa}$ での CCFL-U を計算 した結果を Fig. 11 に示す。計算值では $0.1 \mathrm{MPa}$ 空気・水と $4.1 \mathrm{MPa}$ 蒸気・水との相違は大きいが、

$4.1 \mathrm{MPa}$ と $7 \mathrm{MPa}$ との相違は小さい。 $100^{\circ} \mathrm{C}$ 水 の $\mu_{L}$ は常温水と高温水 $(P=0.6 \sim 4.1 \mathrm{MPa})$ との 中間 (Fig. 6 参照) にあり、Fig. 9 において低圧 の蒸気・水データを追加すれば式(16)の改良もし くは信頼性向上が期待される。

\section{3 両端ラウンドェッジでの管内 CCFL}

CCFL-P に対する $\mu_{G} / \mu_{L}$ の $m$ と $C_{0.5}$ （式(3)で $\beta \approx$ 0.5）への影響を Fig. 12 に示す。CCFL-P では蒸 気・水データがなく、Fig. 4 と Fig. 6 の空気・グ リセリン水溶液の範囲であり、低濃度グリセリン 水溶液 $(m 2$ と $C 2)$ と高濃度グリセリン水溶液 $(m 3$ とC3）の領域になる。そこで、ここでは低濃度 グリセリン水溶液での測定值から高温高圧の蒸 気・水系への外挿性について検討寸る。

低濃度グリセリン水溶液の領域で勾配 $m$ に対 する指数 -0.02 が負になっているが、Fig. 6 では 指数 0.02 であり、使用したデータ群による評価 誤差と判断して $m$ に対する $\mu_{G} / \mu_{L}$ の影響はないと 近似して CCFL-Pデータを整理した。

Fig. 12 における $C_{0.5}$ に対する $\mu_{G} / \mu_{L}$ の指数 0.07 を用いて整理した CCFL-P データを Fig. 13 に示 す $\left(m\right.$ に対する $\mu_{G} / \mu_{L}$ の指数は 0 と近似 $)$ 。Fig. 1 の測定值から対象外の高濃度グリセリン水溶液 を除いている。各測定值 $[11,15,17,18,19]$ の直径 は $19 \mathrm{~mm} 、 18 \mathrm{~mm} 、 25.4 \mathrm{~mm} 、 32 \mathrm{~mm} 、 50.8 \mathrm{~mm}$ で ある。

Fig. 13 に示す測定值を用いて最小二乗法で CCFL 相関式を求めると、次式になる。 


$$
\begin{aligned}
& J_{G}^{* 1 / 2}+0.90 J_{L}^{* 1 / 2} \\
& =(1.58 \pm 0.15) \cdot\left(\mu_{G} / \mu_{L}\right)^{0.07} / D^{* 1 / 8}
\end{aligned}
$$

式(17)では定数 $C_{0.5}$ の不確かさ $\left.\pm 0.15 （ 10 \%\right)$ が、 式(16)と同様に、式(15)での不確かさ \pm 0.05 （約 4\%)より大きい。

式(17)は低濃度グリセリン水溶液の領域に対す る相関式であり、高温高圧の蒸気・水系への外挿 使用は困難と推察される。そこで、CCFL-P では

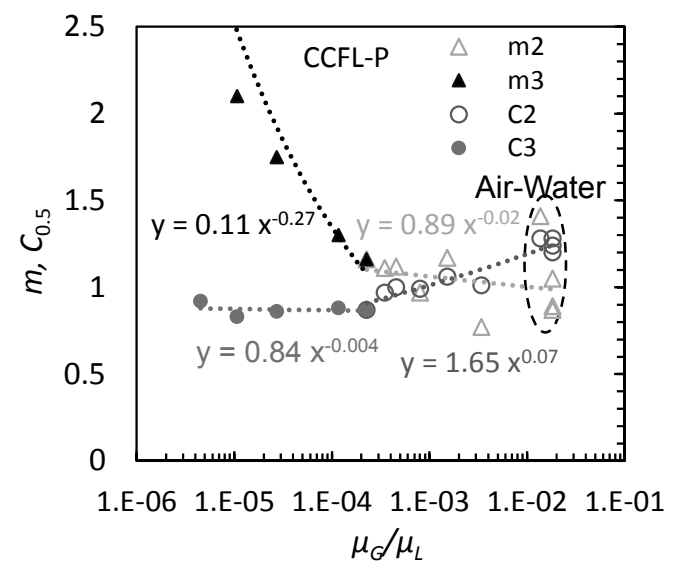

Fig. 12 Effects of $\mu_{G} / \mu_{L}$ on $m$ and $C_{0.5}$ for CCFL-P.

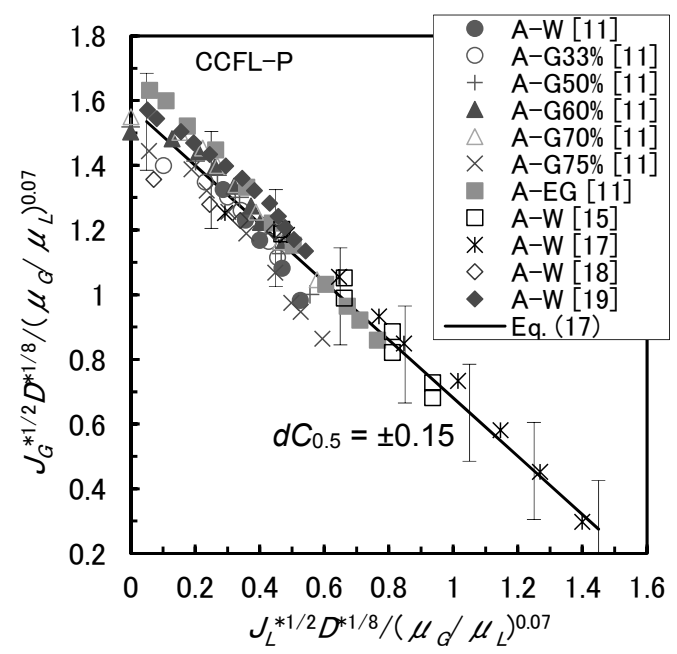

Fig. 13 CCFL-P adjusted by exponent function of $\mu_{G} / \mu_{L}$, A: air, EG: ethylene glycol,

G: glycerol, W: water.
式(3)で $\beta \approx 0.5$ であることから、式(15)と式(16)に おける $m$ と $C$ に対する $\mu_{G} / \mu_{L}$ の指数の平均值 0.25 と 0.10 を使用し、空気・水系で式(17)の $m$ と $C$ に一致する係数を求め、次の参考式を導出した。

$$
\begin{aligned}
& J_{G}^{*_{1} / 2}+2.45\left(\mu_{G} / \mu_{L}\right)^{0.25} J_{L}^{*_{1} / 2} \\
& =1.78\left(\mu_{G} / \mu_{L}\right)^{0.10} / D^{*_{1 / 8}}
\end{aligned}
$$

上式は、式(17)との比較を目的として、 $m$ と $C$ に 対する $\mu_{G} / \mu_{L}$ の指数を仮定したことから式番を (17a)とした。

式(17)と式(17a)を用いて圧力 $7 \mathrm{MPa}$ での CCFL-P を計算した結果を Fig. 14 に示す。大気圧 の空気・水に対しては式(17)と式(17a)による計算 值は一致する。 $0.1 \mathrm{MPa}$ の蒸気・水に対する計算 值の相違は小さいが、 $7 \mathrm{MPa}$ の蒸気・水に対する 計算值の相違は大きい。したがって、CCFL-P 評 価の信頼性を向上するには、蒸気・水実験を行い 流体物性值の影響について確認する必要がある。

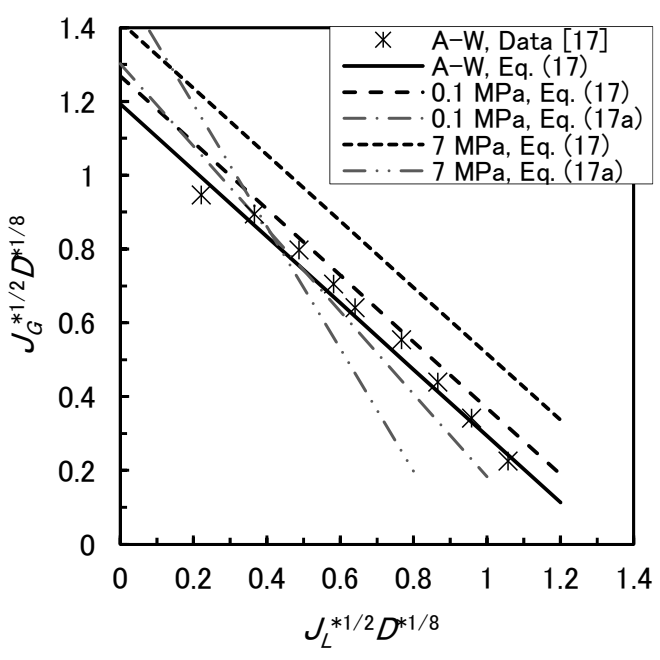

Fig. 14 Effects of pressure on CCFL-P (A-W: air-water, Others: steam-water).

\section{5. 考 察}

本報での検討結果をまとめて Table 1 に示す。 鉛直管での CCFL は、発生位置により 3 種類に分 類され、液相粘性により特性が 3 領域に区分され る。領域の境界值は隣接寸る領域で $m$ もしくは $C$ 
Table 1 Effects of liquid viscosity on $m$ and $C$.

\begin{tabular}{|c|c|c|c|}
\hline Liquid & Water & $\begin{array}{l}\text { Low concentration } \\
\text { glycerol }\end{array}$ & $\begin{array}{l}\text { High concentration } \\
\text { glycerol }\end{array}$ \\
\hline $\begin{array}{l}\text { CCFL-L } \\
(\beta=0) \\
5.6<D^{*}<19\end{array}$ & $\begin{array}{l}m=2.26\left(\mu_{G} / \mu_{L}\right)^{0.29} \\
C_{W}=(1.2 \pm 0.05)\left(\mu_{G} / \mu_{L}\right)^{0.14}\end{array}$ & $\begin{array}{l}m=0.74\left(\mu_{G} / \mu_{L}\right)^{0.02} \\
C_{W}=0.78\left(\mu_{G} / \mu_{L}\right)^{0.03}\end{array}$ & N/A \\
\hline $\begin{array}{l}\text { CCFL-U } \\
(\beta=1) \\
7<D^{*}<51\end{array}$ & $\begin{array}{l}m=2.13\left(\mu_{G} / \mu_{L}\right)^{0.21} \\
C_{K}=(1.98 \pm 0.19)\left(\mu_{G} / \mu_{L}\right)^{0.07}\end{array}$ & N/A & N/A \\
\hline $\begin{array}{l}\text { CCFL-P } \\
(\beta \approx 0.5) \\
6.6<D^{*}<38\end{array}$ & $\mathrm{~N} / \mathrm{A}$ & $\begin{array}{l}m=0.90 \\
C_{0.5}=(1.58 \pm 0.15)\left(\mu_{G} / \mu_{L}\right)^{0.07}\end{array}$ & $\begin{array}{l}m=0.11\left(\mu_{G} / \mu_{L}\right)^{-0.27} \\
C_{0.5}=0.87\end{array}$ \\
\hline
\end{tabular}

が等しくなる $\mu_{G} / \mu_{L}$ である。 $\beta$ は式(3)の代表長さ に関する指標であり、無次元直径 $D^{*}$ は本報で扱 った実験条件の範囲であり式(6)-(8)と同じである。 定数に不確かさを記述しているものは式(15)-(17) と同じであり、不確かさを記述していないものは Fig. 6 および Fig. 12 と同じである（但し、 $C_{0.5}=$ 0.87 は一定值にしており Fig. 12 と異なる)。

実験の多くが空気・水系であり、高温高圧の蒸 気・水データは $D=20 \mathrm{~mm}\left(D^{*}=7.3 \sim 12.5\right)$ に限 られている。例えば加圧器サージ管の鉛直管上端 CCFL-U では約 $D^{*}=100 \sim 150$ になる。したがっ て、原子炉の事故を想定した安全解析では、直径 と圧力に対して外挿計算することになる。予想さ れる不確かさに対して感度解析を行ない、不確か さの影響が大きい場合には実験により不確かさ を小さくして信頼性を向上することが望まれる。

CCFL 実験では、流路形状だけでなく流体の供 給方法や落下水量の測定方法によっても測定值 が大きく異なる場合がある。CCFL 実験データを 取得する際には、Table 1 の 3 分類 (CCFL-L、 CCFL-U、CCFL-P) と 3 領域 (液相粘性が小、中、 大）を参照して取得データの妥当性を確認する、 もしくは従来データとの相違の原因を明確にす ることが望まれる。

\section{6. 結 言}

本報では、鉛直管における CCFL を対象として、 従来データを用いて流体物性值が CCFL 特性に 及ぼす影響について検討し、気液粘性比 $\mu_{G} / \mu_{L}$ を 影響因子に選定し、Wallis 相関式の補正項として 勾配 $m$ と定数 $C$ を $\mu_{G} / \mu_{L}$ の指数関数で表わし、以 下の結論を得た。
(1) $\mu_{G} / \mu_{L}$ による $m$ と $C$ への影響度は 3 領域 (高 温水〜常温水、常温水〜低濃度グリセリン 水溶液、高濃度グリセリン水溶液）に区分 される。影響度が異なる領域への CCFL 相 関式の外挿使用はできない。

(2) $m$ と $C$ には強い相関があり、流体物性值の 補正を行う場合には $m$ と $C$ の両方を補正す る必要がある。

（3）低 $\mu_{L}$ (高温水〜常温水) では $m$ と $C$ は $\mu_{G} / \mu_{L}$ と強い正の相関があり、中 $\mu_{L}$ （常温水～低 濃度グリセリン水溶液) では $m$ と $C$ は $\mu_{G} / \mu_{L}$ との相関が弱く、高 $\mu_{L}$ (高濃度グリセリン 水溶液) では $m$ は $\mu_{G} / \mu_{L}$ と強い負の相関があ る。

(4) シャープエッジ下端での CCFL-L とシャー プエッジ上端での CCFL-U については $\mu_{G} / \mu_{L}$ で補正した Wallis 相関式を用いて $7 \mathrm{MPa} ま$ での蒸気・水系に外挿評価できるが、両端 がラウンドエッジの管内での CCFL-P につ いては蒸気・水データが見当たらず Wallis 相関式を高温高圧の蒸気・水系に外挿評価 することが困難である。

鉛直管での気液対向流に関する研究は多いが、 CCFL データは限られており、特に大口径データ や高温高圧の蒸気・水データは極めて少ない。本 報で示したデータ不足領域を参照して CCFL デ ータを蓄積し、CCFL 相関式の信頼性を向上する ことが期待される。

\section{Nomenclature}

$C \quad$ : CCFL constant

D : diameter 


$\begin{array}{llr}D^{*} & : \text { dimensionless diameter } & {[-]} \\ g & : \text { gravitational acceleration } & {\left[\mathrm{m} / \mathrm{s}^{2}\right]} \\ H^{*} & : \text { dimensionless velocity } & {[-]} \\ J & : \text { volumetric flux } & {[\mathrm{m} / \mathrm{s}]} \\ J^{*} & : \text { Wallis parameter } & {[-]} \\ K^{*} & : \text { Kutateladze parameter } & {[-]} \\ L & : \text { Laplace capillary length } & {[\mathrm{m}]} \\ m & : \text { slope in CCFL correlation } & {[-]} \\ P & : \text { pressure } & {[\mathrm{Pa}]} \\ w & : \text { characteristic length } & {[\mathrm{m}]} \\ \text { Greek letters } & \\ \beta & : \text { exponent in Eq. (3) } & {[-]} \\ \rho & : \text { density } & {\left[\mathrm{kg} / \mathrm{m}^{3}\right]} \\ \mu & : \text { viscosity } & {[\mathrm{Pa} \cdot \mathrm{s}]} \\ \sigma & : \text { surface tension } & {[\mathrm{N} / \mathrm{m}]} \\ \text { Subscripts } & \\ G & : \text { gas phase } & \\ L & : \text { liquid phase }\end{array}$

\section{参考文献}

[1] Wallis, G. B., One-Dimensional Two-Phase Flow, McGraw Hill, New York, 336-345 (1969).

[2] Bankoff, S. G. and Lee, S. C., A Critical Review of the Flooding Literature, NUREG/CR-3060, U.S. Nuclear Regulatory Commission, Washington D.C. (1983).

[3] Kusunoki, T., Doi, T., Fujii, Y., Tsuji, T., Murase, M. and Tomiyama, A., Air-Water Tests on Counter-Current Flow Limitation at Lower End of Vertical Pipes Simulating Lower Part of Steam Generator U-tube, Japanese J. Multiphase Flow (in Japanese), Vol. 28(1), 62-70 (2014).

[4] Kusunoki, T., Murase, M., Fujii, Y., Nozue, T., Hayashi, K., Hosokawa, S. and Tomiyama, A., Effects of Fluid Properties on CCFL Characteristics at a Vertical Pipe Lower End, J. Nucl. Sci. Technol., Vol. 52(6), 887-896 (2015).

[5] Kusunoki, T., Nozue, T., Hayashi, K., Hosokawa, S., Tomiyama, A. and Murase, M., Condensation Experiments for Counter-Current Flow Limitation in an Inverted U-Tube, J. Nucl. Sci. Technol., Vol. 53(4), 486-495 (2016).

[6] Doi, T., Futatsugi, T., Murase, M., Hayashi, K., Hosokawa, S. and Tomiyama, A., Countercurrent Flow Limitation at the Junction between the Surge Line and the Pressurizer of a PWR, Sci. Technol. Nucl. Installations, Vol. 2012, Article ID 754724 (2012).

[7] Richter, H. J., Flooding in Tubes and Annuli, Int. J. Multiphase Flow, Vol. 7(6), 647-658 (1981).

[8] Murase, M., Kusunoki, T., Yamamoto, Y., Mori,
K. and Tomiyama, A., Countercurrent Flow Limitation in Vertical Pipes with the Sharp-Edged Upper End, 11th Int. Topical Mtg. on Nucl. Reactor Thermal hydraulics, Operation and Safety (NUTHOS-11), N11P0014, Gyeongju, Korea, October 9-13 (2016).

[9] Yamamoto, Y., Murase, M., Hayashi, K., Hosokawa, S. and Tomiyama, A., CounterCurrent Flow Limitation inside Vertical Pipes, Japanese J. Multiphase Flow (in Japanese), Vol. 30(4), 392-401 (2016).

[10] Ilyukhin, Yu. N., Balunov, B. F., Smirnov, E. L. and Gotovskii, M. A., Hydrodynamic Characteristics of Two-Phase Annular Flow in Vertical Channels (translated by authors), Teplofiz. Vys. Temp. (in Russian), Vol. 26(5), 923-931 (1988).

[11] Wallis, G. B., Rept. 62GL123, General Electric Co., Schenectady, N.Y. (1962) from Ref. [1].

[12] Bankoff, S. G., Tankin, R. S., Yuen, M. C. and Hsieh, C. L., Countercurrent Flow of Air/Water and Steam/Water through a Horizontal Perforated Plate, Int. J. Heat Mass Transfer, Vol. 24(8), 1381-1395 (1981).

[13] Ilyukhin, Yu. N., Svetlov, S. V., Alekseev, S. B., Kukhevich, V. O. and Sidorov, V. G., The Hydraulic Characteristics of the Process of "Flooding" under Conditions of Countercurrent Flow of Steam and Water in Vertical Tubes, High Temperature, Vol. 37(3), 463-469 (1999).

[14] Zapke, A. and Kröger, D. G., The Influence of Fluid Properties and Inlet Geometry on Flooding in Vertical and Inclined Tubes, Int. J. Multiphase Flow, Vol. 22, 461-472 (1996).

[15] Suzuki, S. and Ueda, T., Behaviour of Liquid Films and Flooding in Counter-Current Two-Phase Flow: 1st Report, Flow in Circular Tubes, Transactions of the JSME [2] (in Japanese), Vol. 44(377), 164-173 (1978).

[16] Yonomoto, T., Anoda, Y., Kukita, Y. and Peng, Y., CCFL Characteristics of PWR Steam Generator U-tubes, Proc. the Int. Topical Mtg. on Safety of Thermal Reactor, 522-529 (1991).

[17] Nichlin, D. J. and Davidson, J. F., The Onset of Instability in Two-Phase Slug Flow, Proc. Symp. Two-Phase Fluid, No.4, Inst. Mechanical Engineers, London (1962).

[18] Clift, R., Pritcherd, C. L. and Nedderman, R. M., The Effect of Viscosity on the Flooding Conditions Wetted Wall Columns, Chem. Eng. Sci., Vol. 21, 87-95 (1966).

[19] Dukler, A. E. and Smith, L., Two-Phase Interactions in Counter Current Flow: Studies of the Flooding Mechanism, NUREG/CR-0619, U.S. Nuclear Regulatory Commission, Washington DC (1979). 